\title{
The Traditional Social Group as A Sociological Factor of the Voting Behavior in the 2015 Karangasem-Bali Local Election
}

\author{
${ }^{1}$ Kadek Dwita Apriani, 2 Riaty Raffiudin \\ ${ }^{1}$ Doctoral Program ofPolitical Science, \\ ${ }^{2}$ Senior Lecturer and Researcher \\ Department of Political Science, FISIP UI \\ Depok 16424, Indonesia \\ Kadek88@gmail.com
}

\begin{abstract}
This article argues that Bali traditional social groups (banjar, kasta, sekaa and dadia) playan important role in determining the voting behavior of the 2015 Karangasemelection. The election raised a surprising result: a female candidate, supported by a coalition of small political parties defeated two other male candidates, one of them was the incumbent and supportedbyPDIP and Golkar. This research applied a quantitative research method where the 420 respondents were collected through a multistage random sampling based on the proportion of voters in every sub-district in Karangasem Regency with 95\% of confident level and 5\% of margin of error. Using the sociological approach of the voting behavior theory, the findings suggest that: (1) the majority of voters in Karangasem are an active member of their traditional social groups, mainly banjar and dadia; (2) $23.8 \%$ of the voters in the 2015 Karangasem Election elected the candidates who were chosen as the favorite candidates in their banjar and dadia; (3) 57.6\% of the voters in the 2015 Karangasem Election followed the political instructions given by kelihan banjar and kelihan dadia regarding who should be voted; (4) The role of kasta were proven to be insignificant to the voting behavior of the Karangasem voters. To conclude, even though the traditional social groups play asignificant role in determining the voting behavior of Karangasem voters in the 2015 local election, this research showed that out of four traditional social groups, dadia, sekaa and banjar emerged as three significant groups compared to kasta.
\end{abstract}

Keywords: Traditional Social Groups, Voting Behavior, Local Election, Karangasem, Bali

\section{INTRODUCTION}

Bali is a region having rich patriarch culture and rigid social structure. In general, woman participation in the process of decision making from the closest surrounding to electoral politic in the province is considered low; however, in 2014 until 2015, there was adifferent phenomenon in one district called Karangasem. The result of two electoral moments, the 2014 legislative election, and the 2015 regional election indicates that the voting behavior of the society in the district is different compared to the other districts in Bali, especially

Regarding the tendency to choose woman politicians. In the 2014 election, there were seven people chosen as the members of Regional Legislative Council (DPRD) of Bali province from Electorate District 7 Karangasem three of which were women: Wayan Sudirta - Ni Made Sumiati; I Gusti Ayu Mas Sumatri - I Wayan Artha Dipa; and I Made Sukerana - I Komang Kisid, two of the three candidates had women candidates. For candidate number 1, the candidate for Vice Regent was awoman. For candidate number 2, Regent Candidate was awoman. Only candidate number three having both men for the position.

\section{Table 1.1 Votes for Candidates during the 2015 Karangasem Local Election}

\begin{tabular}{|c|l|l|r|}
\hline Number & \multicolumn{1}{|c|}{ Candidate } & \multicolumn{1}{|c|}{ Supporting Party } & Vote \\
\hline $\mathbf{1}$ & $\begin{array}{l}\text { Wayan Sudirta - Ni Made } \\
\text { Sumiati }\end{array}$ & PDIP & $30,95 \%$ \\
\hline $\mathbf{2}$ & $\begin{array}{l}\text { I Gusti Ayu Mas Sumatri - } \\
\text { I Wayan Artha Dipa }\end{array}$ & $\begin{array}{l}\text { Nasdem, Hanura, and } \\
\text { PKPI }\end{array}$ & $41,75 \%$ \\
\hline $\mathbf{3}$ & $\begin{array}{l}\text { I Made Sukerana } \\
\text { Komang Kisid }\end{array}$ & $\begin{array}{l}\text { Golkar, Gerindra, and } \\
\text { PKS }\end{array}$ & $27,29 \%$ \\
\hline
\end{tabular}

Source: General Election Commission of Karangasem Regency

The result of the votes of the 2015 Karangasem Local Election shows the unpredictable result for the candidates because most votes were obtained by women candidates 
not carried by two major parties that dominated local politics of Karangasem since 1999,i.e., PDIP and Golkar. Both parties succeeded in positioning their representatives as Chairman of DPRD Karangasem in arrow from 1999 until 2014.Candidates I Gusti Ayu Mas Sumatri - I Wayan Artha Dipa who are supported by the party coalition of Nasdem, Hanura, and PKPI managed to beat I Made Sukerana - I Komang Kisid supported by the Golkar Party, Gerindra, and PKS. ${ }^{1}$ The candidates also have a strong incumbent element. Sukerana is the representative of the incumbent district head who runs for regent.While I Komang Kisid is the sibling of I Wayan Gredeg who was the incumbent. I Gusti Ayu Mas Sumatri - I Wayan Artha Dipa also defeated PDIP candidate I Wayan Sudirta - Ni Made Sumiati.

Candidate number 2, I Gusti Ayu Mas Sumatri - I Wayan Artha Dipa won Karangasem Local Election with the result of 104,560 votes $(41.75 \%)$. In the second position, there was candidate number 1, Wayan Sudirta - Ni Made Sumiati with 77,057 votes $(30.95 \%)$. The third position was candidate number 3; I Made Sukerana - I Komang Kisid who got votes as much as $68,348(27.29 \%){ }^{2}$

The phenomenon of the election of regional heads of women brought together by small parties and succeeded in defeating the votes of incumbent candidates, men, and newlypromoted parties first took place in patriarchal cultures and had clear party identification like Bali. Previously, a general explanation of the potential candidates in many regional elections in Bali has always been linked to several factors such as the identification of political parties in the community; the incumbent position of the candidate or his relative; candidate figure; and policy issues. The factors of traditional social groups are rarely seen, especially in the election of women candidates because these groups in Bali are seen as areas controlled by men.

Bali is known to have cultural peculiarities that greatly affect various aspects of social life of its people. This culture is the root of the traditional Balinese social classification that is unique and can not be found in other parts of Indonesia. The Balinese people embrace the

1"KPU Karangasem Resmi Tetapkan Tiga Paslon" accessed from http://www.karangasemkab.go.id/index.php/baca-berita/6307/KPU-

Karangasem-Resmi-Menetapkan-Tiga-Paslon on 25 January 2017, at 16.15 WIB

${ }^{2}$ Ibid. patriarchal system and have a very neat social organization structure up to the grassroots level. There are various groupings of traditional societies, whether they are vertical or horizontal groupings. Vertical groupings, such as kastabased or so-called color classes. Horizontal grouping in Bali is very diverse and directly in contact with daily life, such as Banjar which is a community based on thesocial organization; Sekaa is a community-based, and social organization based on kinship or clan called dadia / soroh. Such social culture and social structures are believed to influence political life, especially voting behavior in various electoral moments in Bali, including in Karangasem regency.

Ahead of the 2015 Karangasem election, all candidates perform simakrama (socialization) at dadiatemples spread throughout the district. In addition to dadia temple, banjar entity is also the target of candidate socialization and campaign. This indicates the existence of awareness of the candidate that this traditional social organization plays an important role in influencing the political choice of Karangasem community. However, there has never been a deep scientific study of the role of traditional social groups in the form of kasta, banjar, dadia, and sekaa in electoral moments in Bali.

\section{RESEARCH QUESTION}

How is the role of atraditional social group such as dadia, banjar, kasta, and sekaaas the sociological factor in determining the voting behavior of the Karangasem local election in 2015 ?

\section{THEORY AND CONCEPTUAL FRAMEWORK}

\section{Voting Behavior Theory}

Before discussing voting behavior, the concept of voting itself shall be understood first. Voting is similar to the activity of choosing that we usually do in daily life, such as choosing goods. ${ }^{3}$ There is one note from such choice; it may not only affect to individually but also may have collective effects. This differs between voting and choice. When we choose goods in the market for us to buy and take home, then we use them to fulfill the needs, then the effect will be only for us. Such thing will not be found invoting. In the theory of voting behavior, there are three sociological approach or structural social; psychological approach and rational choice

\footnotetext{
${ }^{3}$ Jocelyn A. J., Evans, Voting and Voters: An Introduction, (London: SAGE Publications, 2004), page. 3.
} 
approach. Int his study, the sociological approach is used.

The sociological approach in voting approach states that the most influencing factor in people's choice during the election is the social characteristic and grouping. One's voting behavior is related to thesocial group from which such individual comes from. It means that social characteristic determines the political tendency of someone. Social grouping here means age, gender, religion, occupation, social economy class, regional, family background, activities in formal and informal groups being followed. These social groups are considered very influential in the decision to vote since these groups play a role in the foundation of one's attitude, perception, and orientation.

\section{Social Group Role in Candidate Partiality}

The sociological approach to voting behavior states that the factors that most influence people's choices in the elections are social characteristics and groupings. Dieter Roth mentions that the behavior of one's vote concerns the social group from which the individual originated. ${ }^{4}$ It means that social characteristics determine one's political tendencies. The social groupings referred to here are age, sex, religion, occupation, socioeconomic class, regionalism, family's background, and activities in formal and informal groups. These social groups are seen as having a majorinfluence on the decision to vote because they play a role in the foundation of one's attitude, perception, and orientation.

Research regarding voting behavior in transitioning countries was conducted in the Philippines by Steven Rood, and in one of the countries in Africa region, Malawi. Based on such different research, it can be concluded that there is asimilarity. Voting behavior in transitioning countries is not affected significantly by the policy issue and party orientation; instead, it is more influenced by issue related to the candidates and their ties such as ethnics, place of origin and clientelistic relation in the social community structure ${ }^{5}$

In the election of individual candidates in the Philippines, such as the presidential election, the most powerful factor influencing the political choice of its citizens is the candidate factor.

${ }^{4}$ Dieter Roth, Studi Pemilu Empiris: Sumber, Teori, Instrumen, dan Metode, translated. (Jakarta: Friedrich-Naumann Stiftung fur die Freiheit, 2008), page. 25.

${ }^{5}$ Steven Rood, "Perspective on the Electorals Behaviour of Baguio City (Philipines) Voters in Transition Era," Journal of Southeast Asian Studies, Vol. 22 No. 1 (Maret 1991), page. 86-87.
Another factor to be seen is the ethnicity of the candidate in question and the strongclient's patron structure in the community. People prefer to vote for candidates who are coming from the same ethnic as they are and can communicate with the ethnic language in question bersangkutan. ${ }^{6}$ While in Malawi, the fact that people determine their political choice based on ethnic factors and their origin areas is because people identify themselves by the political power of the past that they re-present in the seizure of power through the election. ${ }^{7}$

The research on the voting behavior in Indonesia that has been conducted by Afan Gaffar emphasizes the importance of social characteristics, especially socio-religious orientation in viewing voter behavior in Java Island ${ }^{8}$. Other research on voting behavior in Indonesia was conducted by looking at the 1999 election. The results mentioned that social ties are mainly important ethnic factors to note when we want to observe the behavior of voting Indonesians. ${ }^{9}$ The importance of social ties such as ethnicity in influencing people's political choices was also put forward by Benny Subianto who examined Local Election in six districts in West Kalimantan. This factor is influential because people's loyalty to ethnicity is still high, and they see that the same ethnic means have the same cultural values; hence, thesocio-political behavior is seen as a mirror of identity. ${ }^{10}$

The sociological factors or social groups and their influence on the voting behavior Indonesians were studied by Saiful Mujani and colleagues by analyzing empirical data generated through national surveys in 2004 and 2009. Mujani's findings show there are three sociological variables that significantly influence the political choice of Indonesian society in the Election and the Presidential Election in 2004 and 2009, namely religion, regionalism, and education level. ${ }^{11}$

\footnotetext{
${ }^{6}$ Ibid., page. 105.

${ }^{7}$ Deborah Kaspin, "The Politics of Ethnicity in Malawi's Democratic Transition," Journal of Modern Afrikan Studies, Vol. 33 No. 4 (Desember, 1995), page. 617.

${ }^{8}$ Afan Gaffar, Javanese Voters: A Case Study of Election Under a Hegemonic Party System (Yogyakarta: Gajah Mada University Press, 1992), page. 120-121.

9 Dwight Y. King, Half-Harted Reform: Electoral Institution and Strugle for Democracy in Indonesia (USA: Praeger Publishers, 2003), page. 149.

${ }^{10}$ Maribeth Erb dan Priyambudi Sulistiyanto, Deepening Democracy In Indonesia: Direct Election for Local Leaders (Singapura: Institute of Southeast Asian Studies, 2009), page. 335.

${ }^{11}$ Saiful Mujani et. al., Analisis tentang Perilaku Memilih dalam Pemilihan Legislatif dan Presiden Indonesia Pasca-Orde Baru, (Jakarta: Mizan Publika, 2011), page. 301.
} 


\section{Traditional Social Group in Balinese Hindu Community}

The social peculiarities of Balinese society can be seen from the traditional social groups that are difficult to meet in other areas, such as the ties that local people callKasta,dadia, banjarand, sekaa. These ties are allegedly influential in the selection of local leaders such as Local Election ${ }^{12}$. This tendency occurs because of a special political culture in Bali called Briuk Siu which means that individual political choice is not an autonomous option, but follows the choice of the majority of its members. ${ }^{13}$

Kasta is a social group that is hierarchical in the social order of Hindu society, meaning that rulers or leaders are those who are descendants of the Kasta Triwangsa (Brahmana, Ksatria, and Waisia), while those who are from Sudra level should not be leaders. ${ }^{14}$ In fact, the number of people with Sudra level is much more than the other three. The existence of a social class based on this birth has been protested heavily by the Balinese Hindu community, but this social order still exists today. The existence of social bonding in Bali is often also called Warna is very easily observed by seeing the use of the title of nobility as the first name.

In addition to Kasta, there is another tie in Bali called Dadia. This tie is a social tie based on the inheritance. ${ }^{15}$ Different from Kasta that segregates the people into four big groups, Dadia in Bali, in general, are so many and has never identified or dated stating the number ofDadia existing in Bali. However, there are several big and solid Soroh such as Soroh Pasek, Arya, Dalem, Pande, and Bujangga Waisnawa.16 These big Soroh are distributed into smaller groups called Dadia.

The existence of kasta tie based on Hinduism in Bali can be traced long before colonial times. ${ }^{17}$ While Soroh tie has existed since the 1950s which began to emerge and increasingly strengthened in the Balinese society as a form of protest over the hierarchical structure of caste

\footnotetext{
12 Yuliana Rini, "Peta Politik Bali: Benteng Nasionalis yang Masih Eksis", inKompas, edition Saturday 7 March 2009, page. 8.

${ }^{13}$ A. A. G. N. Ari Dwipayana, "Geneologi Politik: Desa Adat bali dan Ruang Demokrasi," in I Nyoman Dharma Putra (Ed.), Bali Menuju Jagadhita: Aneka Perspektif (Denpasar: Pustaka Bali Post, 2004), page. 69-70.

${ }^{14}$ Ketut Wiana dan Raka Santeri, Kasta dalam Hindu: Kesalahpahaman Berabad-abad (Denpasar: Dharma Narada, 2002), page. 116.

${ }_{15}$ Putu Setia, Bali yang Meradang (Denpasar: Pustaka Manik Geni, 2006), page. 211.

16 I Ketut Gobyah, "Pura Pedarman Pasek di Besakih", accessed fromhttp://www.balipost.com/balipostcetak/2007/7/11/bd1.htm, on 22 December 2016, at 21.12 WIB.

${ }^{17}$ Leo Howe, Hinduism and Hierarchy in Bali (Santa Fe: School of American Research Press, 2001), page. 22.
}

rooted in Bali. ${ }^{18}$ Soroh / Dadia affects the political choices of citizens in the election of a very local leader such as the selection of Kelihan Banjar or the head of the hamlet, Kelihan Subak or the head of the irrigation and Bendesa or the village chief who has since been elected directly by adult males in the territory. ${ }^{19}$ Kasta can be seen as influencing the succession of the Balinese kingdom. Both ties are never extinct and disappear altogether, but their influence has been up and down from such ties in Balinese political behavior. ${ }^{20}$

Kasta for a long time has influenced modern political life in Bali. Leo Howe notes that from 1966 to 1998 under the Soeharto regime, Kasta played an important role in politics, as evidenced by the position of the governor and the eight regents of Bali at that time were dominated by those coming from Triwangsa background. ${ }^{21}$ This continued until the reformation period, even to the districts of Bali entering the era of thedirect regional election in 2005 , the traditional aristocracy nuance was still very strong. ${ }^{22}$ These symptoms are still present, but the degree is said to be decreasing in Regent election in some districts in Bali in 2008. Local aristocracy factors seem to decrease when the results of the 2013 Bali Governor election shows that Made Mangku Pastika - Ketut Sudikerta who are coming from sudra level defeated Anak Agung Ngurah Puspayoga -Dewa Sukrawan coming from kastatriwangsa.

The decrease in the influence of kasta factor raises the hypothesis of strengthening the influence of other traditional groups in electoral momentum from 2013 to 2015. Soroh factor and Sub Soroh / Dadia are allegedly significant in the election Mangku Pastika in Bali Regional Election and election of Eka Wiryastuti in Tabanan Regional Election.23 Kurniawati Hastuti Dewi's research on the election of Eka Wiryastuti in Tabanan Bali district shows that Eka and her winning team can hold control over the social-

\footnotetext{
${ }^{18}$ Leo Howe, The Changing World of Bali: Religion, Society and Tourism (New York: Routladge, 2005), page. 126.

${ }^{19}$ Hildred Geertz dan Clifford Geertz, Kinship in Bali (Chicago: University of Chicago Press, 1975), hlm. 107.

${ }^{20}$ Putu Fajar Arcana, Surat Merah untuk Bali (Yogyakarta: Galangpress, 2007), page. 152.

${ }^{21}$ Leo Howe, 2001, Op.Cit., page. 82-83.

${ }^{22}$ Graeme McRae dan I Nyoman Darma Putra, "Not Just An Elite Game", inInside Indonesia, No 97, July-September 2009, accessed fromhttp://insideindonesia.org/content/view/1212/47/, on 15 October 2009, at 16.40 WIB.

${ }^{23}$ Kurniawati Hastuti Dewi et. al., Kebangkitan Perempuan Tabanan dalam Politik Lokal, (Jakarta: Kerja sama Pusat Penelitian Politik LIPI dengan Mahara Publishing, 2016), page. 144.
} 
cultural network of soroh/dadia Pasek having the most members in Tabanan. ${ }^{24}$

\section{RESEARCH METHOD}

This research is using thequantitative method. The quantitative political research means to use the measurement in the analysis of behavior or attitude. ${ }^{25}$ The main data collection was conducted through structured interview of respondents using questionnaire. The population in this research is the community in Karangasem-Bali district that meets all of the requirements to vote in the 2015 Karangasem Regional Election (those who are above 17 years old, and or are married). The sample taken to represent this population is 420 respondents with the Margin of Error (MoE) 5\%. The data collection was conducted several months before the election.

Furthermore, the sample collection technique used in this research is Multistage Random Sampling due to the heterogenic population. Respondents were chosen by paying attention to the proportion of total voters per district in Karangasem regency. Moreover, the total sample in each district is different based on the total proportion of voters in such district. In each district, several random villages were taken based on the district proportion. In each village, 5 simply random kampongs were chosen. In each Neighborhood Association (RT)/kampong, 2simply random families were chosen, and in each family, one respondent was taken using the Kish Grid system. The gender proportion in this research is maintained to have the 50:50 with the mechanism of using odd questionnaire number for male and even questionnaire number for female respondent. The data processing is conducted using descriptive statistic in the form of frequency and cross tabulation.

\section{FINDING AND ANALYSIS}

Before going further regarding the finding, the demographic of therespondent in Karangasem is necessary to be explained. Table 2 below explains the regional distribution, age, education and social economy status aspects of the respondents in this research.
Table 2 Demographic Voter

\begin{tabular}{|l|c|l|c|}
\hline \multicolumn{1}{|c|}{ Region } & persentage & \multicolumn{1}{|c|}{ Education Level } & persentage \\
\hline Abang & 16.7 & Graduated from Primary School & 28.8 \\
\hline Bebandem & 11.9 & Graduated from Junior High School & 16.9 \\
\hline Karangasem & 11.9 & Graduated from Senior High School & 27.1 \\
\hline Kubu & 16.7 & Academy (D1 or D3) & 2.6 \\
\hline Manggis & 11.9 & Bachelor Degree & 5.7 \\
\hline Rendang & 9.5 & Ungraduated & 5.0 \\
\hline Selat & 11.9 & Uneducated & 12.6 \\
\hline Sidemen Age & 9.5 & Not Answer & 1.2 \\
\hline \multicolumn{1}{|c|}{ Age } & \multicolumn{1}{|c|}{ Income } & persentage \\
\hline 17-25 years old & persentage & & 40.0 \\
\hline $26-35$ years old & 8.8 & Less than Rp 500.000 & 32.9 \\
\hline $36-45$ years old & 25.7 & Rp 510.000 - Rp 1.000.000 & 17.4 \\
\hline 46-55 years old & 31.9 & Rp 1.100.000 - Rp 2.000.000 & 4.3 \\
\hline 56-65 years old & 16.9 & Rp 2.100.000 - Rp 3.000.000 & 3.3 \\
\hline$>66$ years old & 10.5 & $>$ Rp 3.000.000,- & 2.1 \\
\hline
\end{tabular}

The table above indicates that respondents in this survey have represented the population of voters in Karangasem. All segments of the voter were reached proportionally. Such data provides the information regarding educational background and welfare of the community in this regency. The majority of people in Karangasem has the educational background of middle or lower (High School and Elementary School graduates). Almost $90 \%$ of the voters live with the average of income less than Rp. 2.000.000,per month.

The research findings presented in Figure 1 below show the voter membership in Karangasem in a variety of traditional social organizations that are very typical in Bali. A total of $82.9 \%$ of the Karangasem community stated that they were members of a traditional banjar. The percentage of community membership in a clan-based group called dadia was lower than the banjar membership. Respondents who claimed to be members of a dadia were $60.5 \%$. Membership of sekaai.e. groups based on hobby associations/hobbies is much lower than the membership of two other traditional social groups. Respondents who claimed to be members of a sekaa in Karangasem amounted to $23.6 \%$

Figure 1 Karangasem Community Membership in Traditional Social Organization

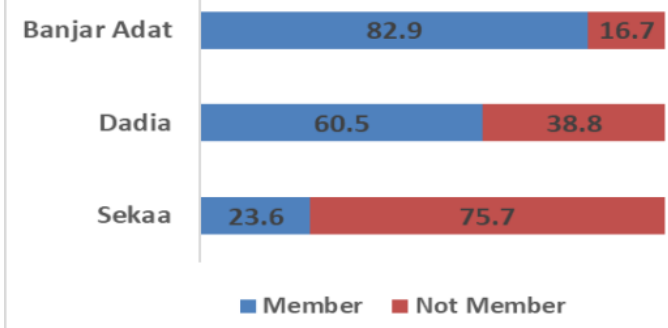

The findings above explain that the traditional social group ties in eastern Bali are still very

\footnotetext{
25 Lisa Harison, Metode Penelitian Politik, terj. (Jakarta: Kencana, 2009), page. 15.
}

${ }^{24}$ Ibid. 
strong. Banjar which is a region-based residence organization is a very important social organization because almost all indigenous activities in Bali involve this organization. Hence, more than $80 \%$ of the people remain attached to this organization.

The data in Figure 1 also gives clues as to how much potential dadia is in mobilizing voters since the sentiment in this organization is kinship sentiment. Apparently, Karangasem people who are members of this clan-based group is more than $50 \%$. Regarding number, membership in these three traditional social organizations is so significant that the channel of socialization and the campaign of candidates in an electorate district is relatively clear. In Bali, candidate and community meetings with traditional social groups located in banjar hall and dadiatemple are called simakrama. The fact that whether the respondent has been involved in such simakramabecomes an important indicator in this research because the number of membership of social group seen in the new figure 1 is limited to thepotential number. Participation in simakrama activity is one form of activation of that potential.

Data on community participation in simakrama activities conducted in centers of traditional social activities are not as large as their membership in traditional social organizations. The following figure indicates such thing

Picture 2 The involvement in simakramaconducted by Regent/Vice Regent Candidates

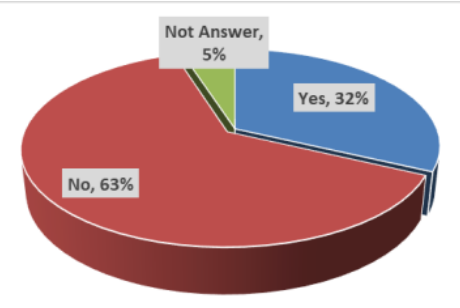

Only $32 \%$ of respondents stated that they had participated in simakrama of candidates in their banjar,dadia or sekaa. If cross-tabulated between membership in these three organizations with the tendency of respondents to participate in simakrama (socialization/campaign/face-to-face meeting between candidates and the people), these three tables below indicate, the data obtained.
Table 3 Cross Tabulation between Banjar

Membership and participation in simakrama

\begin{tabular}{|l|c|c|c|}
\hline \multirow{2}{*}{$\begin{array}{c}\text { Memnbership in } \\
\text { Banjar }\end{array}$} & \multicolumn{3}{|c|}{ Involvement in Simakrama } \\
\cline { 2 - 4 } Member & Yes & No & Not Answer \\
\hline Not Member & $34.8 \%$ & $60.1 \%$ & $5.2 \%$ \\
\hline
\end{tabular}

Table 4 Cross Tabulation between Dadia

Membership and participation in simakrama

\begin{tabular}{|l|c|c|c|}
\hline \multirow{2}{*}{$\begin{array}{c}\text { Memnbership in } \\
\text { Dadia }\end{array}$} & \multicolumn{3}{|c|}{ Involvement in Simakrama } \\
\cline { 2 - 4 } Member & Yes & No & Not Answer \\
\hline Not Member & $37.4 \%$ & $59.4 \%$ & $3.1 \%$ \\
\hline
\end{tabular}

Table 5 Cross Tabulation between Sekaa

Membership and participation in simakrama

\begin{tabular}{|l|c|c|c|}
\hline \multirow{2}{*}{$\begin{array}{c}\text { Memnbership in } \\
\text { Sekaa }\end{array}$} & \multicolumn{3}{|c|}{ Involvement in Simakrama } \\
\cline { 2 - 4 } Member & $42.4 \%$ & $55.6 \%$ & $2.0 \%$ \\
\hline Not Member & $29.2 \%$ & $65.7 \%$ & $5.0 \%$ \\
\hline
\end{tabular}

The three tables above show how community membership in a traditional social organization increases their chances of participating in the candidate's simakrama. Members of traditional social organizations that mostly participate in simakrama are members of sekaa. A total of $42 \%$ of the respondents who claimed members of one sekaa entity stated that they had participated in the candidate's simakrama. In dadia entities, as many as $37 \%$ of those admitted members claimed to have attended simakrama. The smallest percentage of members who had attended the simakramawas seen in banjartraditional social group (34\%). It also shows that the greater the number of members, the less chance the members participating in simakrama.

In addition to membership in traditional social groups and participation in simakrama, the influence of social groups in determining the political choices of the community can be seen from the influence of the traditional group's recommendations to the political choice of the community. Figure 3 below shows data on leaders most followed or heard or considered for their political suggestion by the people of Karangasem district in the 2015 election. 
Figure 3 Leaders whose Political Suggestion is the Most Followed

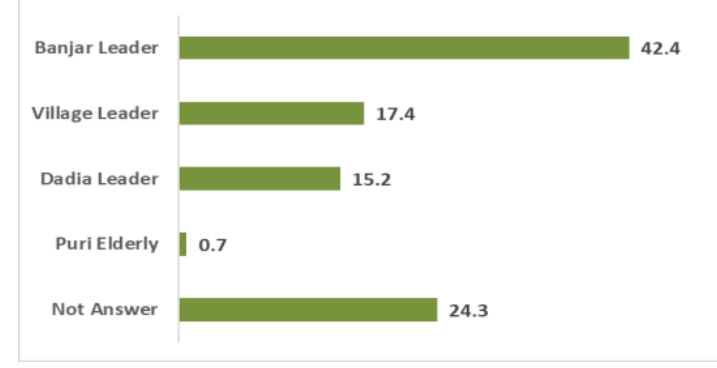

The data above shows that the kelihanbanjar or banjar traditional group leader is the opinion leader whose political suggestion is the most followed by the community. A total of $42.4 \%$ of respondents admitted that they followed the kelihanbanjar political suggestion in various electoral momentum, including determining political choice in the 2015 regional election. Meanwhile, the number of people who stated that they most followed the political recommendation from kelihandadiaor the elderly from dadia as much as $15.2 \%$. This data emphasizes the notion that the influence of traditional social groups on voting behavior in Bali generally and Karangasem, in particular, is still very strong. If the influence of kelihandadia and banjar were combined, $57.6 \%$ was obtained. This number is the number of voters who follow the recommendation from Karangasem elders or leaders of traditional social groups. The influence of traditional social groups on the choice of Karangasem society in the election is even greater than the influence of political parties. The respondents stated that they chose the candidates because they were the candidate for the majority of the people in dadia and banjar area up to $23.8 \%$, while those who voted voted for the influence of the candidate party's political party was less than $2 \%$. This is also an indicator of weak identification of political parties in Karangasem community. No wonder the candidates supported by two major parties suffered aloss during the electoral momentum in 2015.

This grouping is somewhat different from the three other social groupings described above. If banjar, dadia, and sekaa are social groupings that are horizontal, then kasta is more vertical. Kasta in Bali is divided into four major groups namely Brahmins, Knights, Waisya, and Sudras. In the past, leaders came from three high kasta called tri wangsa, while the common people were sudra.

In the context of the 2015 Karangasem election, which was followed by three pairs of thecandidate, only one couple had the tri wangsa, the couple who won the election, I Gusti Ayu Mas Sumatri - I Wayan Artha Dipa. The other two pairs are only filled by sudra level. This condition raises the suspicion of the influence of caste in the decision to elect society in the election. To confirm this, there are two indicators used in this study, namely (1) how important the tri wangsa kasta background of the candidate in the eyes of the voters, and (2) how the voters see the puri background of (local aristocracy generally filled by the ksatria) the ideal regent and vice-regent in Karangasem. Figures 4 and 5 below present findings on the two caste indicators.

Figure 4 Voters Orientation Regarding Kasta Background of Candidates

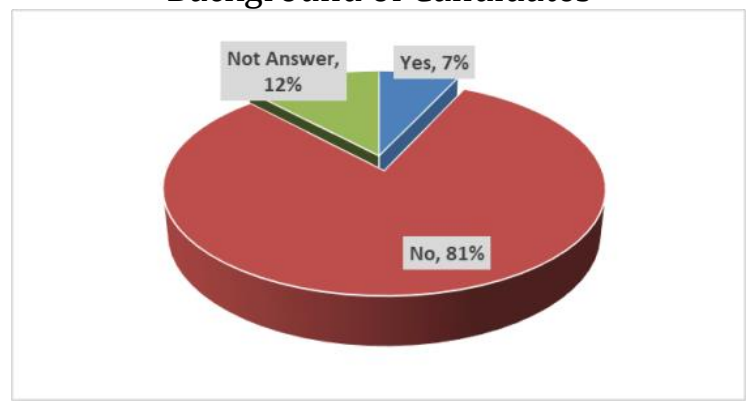

Figure 5 Puri Background Preference from Candidates of Regent and Vice Regent

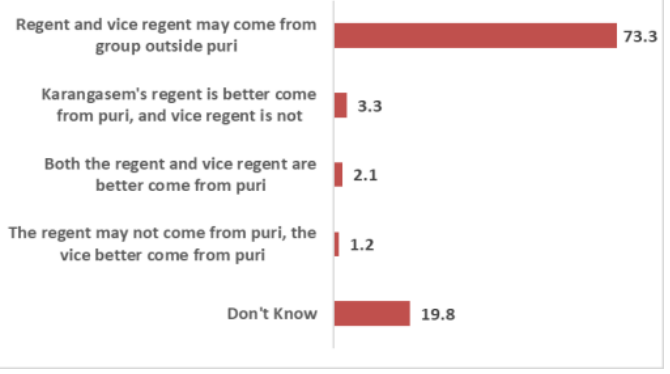

Picture 4 shows that only $7 \%$ of the total voters in Karangasem stated that the candidate background of kasta tri wangsais the most important thing in considering the candidates for regent and vice-regent during the 2015 local election. The majority of voters (81\%) stated that kastais not important to be considered in determining thepolitical choice. That was confirmed in the second indicator regarding kastaand local aristocracy. Only $6.6 \%$ of the voters thought that it was ideal to have puri (kastaksatria) for the candidates of theregional chief of Karangasem in 2015.

The findings presented above show that traditional Balinese social groups influence people's voting behavior in the elections of Karangasem in 2015. When viewed from the theory of voting behavior, these traditional social 
groups in Bali can be classified as sociological factors, because the sociological approach in the behavioral theory chooses to mention that social groups are the most important element in influencing voting behavior in an electoral moment. Furthermore, this research can explain which traditional social groups most influence the behavior of choosing and ways that can be used to influence the behavior of choosing in Karangasem via the traditional social group. The study found that not all traditional social groups in Karangasem-Bali influenced the political choice of their communities. of the four traditional social groups namely banjar, dadia, sekaa, and kasta, traditional kasta social groups are the least considered factors by voters. On the other hand, traditional banjar social groups are the most important in influencing voting behavior, followed by dadia, then Sekaa. There are at least two ways candidates to influence the voting behavior of the Karangasem community through these three traditional social groups: (1) performing simakrama in banjar, dadia, and sekaa; and (2) exploit the leader (kelihan) of banjar, dadia, and sekaa to persuade krama or members to exercise the right to vote because more than $50 \%$ of voters said they would follow the recommendations of kelihan banjar and kelihan dadia in determining political choices.

\section{CONCLUSION}

This research concludes that the social traditionalgroup in Karangasem-Bali influences the choosing behavior of the community during the regional election of Karangasem in 2015. Such social traditional group which may be considered as sociology factor in choosing behavior of the community of Karangasem during the 2015 regional election are banjar, dadia, and sekaa. Each of them is social grouping based on regional, clan and hobby. Direct meeting between candidates and members of the three traditional social groups and the instruction of the leaders from each group were the best way fo the candidates in increasing the chance to get elected.

One traditional social group is not considered as important by the people in determining their political preference. This grouping is called kasta. This indicates that there is shifting in sociological factors in thevoting behavior of Bali community. In the past, kastafactor is considered important in theelectoral moment, so there was aphenomenon in which the political parties are approaching local aristocracy figures in Bali to get the votes. This research indicates that kastafactor in local politic in Bali has been faded away. Despite the fact that the elect candidate in 2015 Karangasem local election was the only candidate with ksatria level, the voters stating kastabackground as animportant consideration in their political choice were only $7 \%$ of the total which was way less than those who stated that kastafactor was not important (81\%).

Two approaches frequently used by the candidates in taking advantage oftraditional social group in anelectoral moment in Karangasem is by doing simakramaand getting near the kelihanbanjar, dadia, and sekaa. These traditional social groups are very effective for socializing due to the obvious number of its members and in general follow the instruction and suggestion of the leaders.

\section{REFERENCES}

\section{Book}

Arcana,Putu Fajar, 2007,Surat Merah untuk Bali, Yogyakarta: Galangpress

Dewi, Kurniawati Hastuti dkk., 2016, Kebangkitan Perempuan Tabanan dalam Politik Lokal, Jakarta: Kerja sama Pusat Penelitian Politik LIPI dengan Mahara Publishing

Erb, Maribeth dan Priyambudi Sulistiyanto, 2009,Deepening Democracy In Indonesia: Direct Election for Local Leaders, Singapura: Institute of Southeast Asian Studies

Evans, Jocelyn A. J., 2004, Voting and Voters: An Introduction, London: SAGE Publications

Gaffar,Afan, 1992,Javanese Voters: A Case Study of Election Under a Hegemonic Party System, Yogyakarta: Gajah Mada University Press Geertz, Hildred dan Clifford Geertz, 1975, Kinship in Bali, Chicago: University of Chicago Press Harison, Lisa, 2009,Metode Penelitian Politik, Jakarta: Kencana

Howe, Leo, 2001,Hinduism and Hierarchy in Bali, Santa Fe: School of American Research Press

Howe, Leo, 2005, The Changing World of Bali: Religion, Society and Tourism, New York: Routladge

King,Dwight Y., 2003,Half-Harted Reform: Electoral Institution and Strugle for Democracy in Indonesia, USA: Praeger Publishers

Mujani, Saiful dkk, 2011, Analisis tentang Perilaku Memilih dalam Pemilihan Legislatif dan Presiden Indonesia Pasca-Orde Baru, Jakarta: Mizan Publika

Putra, I Nyoman Dharma(Ed.), 2004,Bali Menuju Jagadhita: Aneka Perspektif , Denpasar: Pustaka Bali Post 
Roth,Dieter, 2008,Studi Pemilu Empiris: Sumber, Teori, Instrumen, dan Metode, Jakarta: FriedrichNaumann Stiftung fur die Freiheit

Setia, Putu, 2006,Bali yang Meradang, Denpasar: Pustaka Manik Geni

Wiana, Ketut dan Raka Santeri, 2002,Kasta dalam Hindu: Kesalahpahaman Berabad-abad, Denpasar: Dharma Narada

\section{Journal}

Kaspin,Deborah "The Politics of Ethnicity in Malawi's Democratic Transition," Journal of Modern Afrikan Studies, Vol. 33 No. 4 (Desember, 1995)

Rood,Steven, "Perspective on the Electorals Behaviour of Baguio City (Philipines) Voters in
Transition Era," Journal of Southeast Asian Studies, Vol. 22 No. 1 (Maret 1991)

\section{Printed Media}

Kompas, edisi Sabtu 7 Maret 2009

\section{Website}

http://insideindonesia.org/content/view/1212/ 47/

http://www.balipost.com/balipostcetak/2007/7 /11/bd1.htm

http://www.karangasemkab.go.id/index.php/ba ca berita/6307/KPU-Karangasem-ResmiMenetapkan-Tiga-Pas 